UDC 821.163.41-31.09 Petrović R.

https://doi.org/10.18485/ms_zmskij.2020.68.3.4

Др Предраг Ж. Петровић

\title{
РАСТКО ПЕТРОВИЋ И АМЕРИЧКА КУЛТУРА
}

Рад је посвећен позном стваралаштву Растка Петровића насталом за време његовог живота и рада у Сједињеним Државама. Као и бројни српски књижевници прве половине прошлог века и Петровић је био у дипломатској служби. Након неколико година које је провео у посланству у Риму, Растко је новембра 1935. године стигао у Сједињене Државе где ће радити у југословенским конзулатима у Чикагу и Њујорку а потом као отправник послова у Вашингтону. У Америци Растко Петровић наставља свој књижевни рад и уметничка интересовања. У Растковим остварењима насталим у Америци - у другом делу романа Дан щестии и у кратким документарним филмовима које је снимао, преовладавају слике и доживљаји природе у којој је овај аутор носталгично налазио нешто што га је подсећало на завичај у Србији. Визије природе у другом делу Дана щеестио̆ заправо су вишеструко посредоване симболима и знањима који су произведени културом, првенствено америчком историјом, традицијом и књижевношћу.

Кључне речи: роман, Америка, култура, документарни филм, поезија, природа, историја, политика.

Док Вук Исакович у Сеобама Милоша Црњанског сања о непрегледним пољима Русије кроз које ће јахати коње и живети слободним, неспутаним животом, Стеван Папа-Катић, јунак романа Дан щеесии Растка Петровића, срећу налази у пространствима и градовима Америке. Од авангардног Дневника о Чарнојевићу до позномодернистичког Романа о Лонgону, проза Црњанског обликује сложену слику Русије, у распону од суматраистичке и утопијске визије, потом геополитичке пројекције и историјске реалности до књижевне фасцинације и меланхоличне жудње. Сједињене Државе фигурирају само у другом делу Растковог последњег романа, али се, ипак, успостављају у богатом мозаику књижевних, политичких и културолошких значења. У могућем самеравању поетика Црањанског и Петровића овај однос 
према двема моћним државама и културама које су битно утицале на профилисање модерног света, вероватно се не би могао посматрати изван увек актуелног питања позиције српског идентитета између Истока и Запада. Али тај однос се, свакако, не би могао свести на подвојеност или избор између две, углавном супротстављене, опције. За Црњанског је иницијални моменат интересовања за Русију била, очекивано, њена књижевност, потом откриће мемоара Симеона Пишчевића, проучавање сеоба Срба из Хабзбуршке монархије половином осамнаестог столећа те, коначно, сусрети са руским емигрантима у Лондону након Другог светског рата. За Растка су били пресудне животне околности, односно дипломатска служба која ће га одвести пут новог континента. Зато се питање односа овог аутора према америчкој традицији, уметности и друштву додирује са две важне теме српске културе у протеклом веку. Многи наши књижевници били су професионално ангажовани у дипломатији (Митић 2002) што је оставило трага у њиховим делима. Поменимо циклус песама На Косову Милана Ракића, Дучићеве путописе Граяови и химере, Андрићев роман Травничка хроника или књигу Kog Хийерборејаиа Милоша Црњанског. Други могући контекст унутар којега се може посматрати Растков рад и боравак у Сједињеним Државама тиче се позиције и значаја Срба у Америци. Од половине деветнаестог века расте број српских усељеника на америчком тлу и многи од њих даће огроман допринос науци и уметности, од Михајла Пупина и Николе Тесле до Славка Воркапића, Стива Тешића или Чарлса Симића (VIDAković-Petrov 2015).

Растко Петровић био је опчињен путовањима и упознавањем разли-

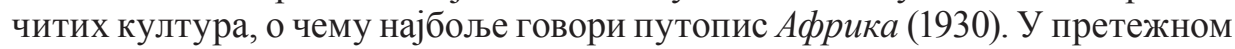
делу његовог опуса доминира хронотоп пута и сусрета. „Растко је себе осећао највише као путника”, вели Винавер, „Тај му је симбол био најдражи. Путник једнако нешто открива. Путник никада није стигао, ни ишта усталио: после пута, опет предстоји - пут” (ВинАвер 1975: 399). Зато и не чуди што је након путовања по Европи и Африци Петровићев сан био је да оде у Америку, земљу у којој се сусрећу и сукобљавају различите културе и субкултуре, токови традиције и модернизације. Указом краљевских намесника Растко је септембра 1935. године именован за вицеконзула у Чикагу и већ у новембру, након што је завршио роман Осам неgељ $а$, који ће касније постати први део Дана ще естио̄, креће на далеки пут. О првом сусрету са Америком опширно је, марта 1936, писао Милици Ракић, супрузи песника и дипломате Милана Ракића:

„Питате ме као ми се овде допада. Рећи ћу Вам само да су ми при поласку казали да ће ми требати шест месеци да заволим Америку. Од првог часа, међутим, од момента када се профил Њујорка појавио кроз маглу, чини ми се да сам је заволео. Истина, првих десетак дана био сам без даха, стегнутог срца и ошамућен. Све је изгледало као у оном римском тунелу под Квириналом. И онда се лаганао открије да је Америка једна пасторална земља, највећа пасторална земља на свету, са безмерним 
осунчањима, сенкама, разливеним водама, ветровима. Кампања Романа или Шумадија милион пута увећана. Усред милионских градова, стоспратних билдинга и шестоструке реке аутомобила, људи су задржали кампањерски излед, детињску ведрину и гостољубље, које је за нас позне Европљане, иако се хвалимо гостољубљем, потпуно фантастично. (...) Цео тај темпо изгледа лудачки, детињаст и без срца, а у ствари је проткан таквом ведрином, одмереношћу и таквом детињском и кампањерском романтиком, да је Америку заиста немогуће не заволети“ (ПЕтровић 2003: 229-231).

У Растковим остварењима насталим у Америци - у другом делу романа Дан щестии као и у кратким документарним филмовима које је снимао - доминираће слике и доживљаји природе у којој је овај аутор увек носталгично тражио и налазио нешто што га је подесећало на завичај у Србији. Међутим, импресију о Америци Растко је формирао и пре него што је ступио на њено тло. У низу есеја које је објавио 1931. у листу Време под насловом

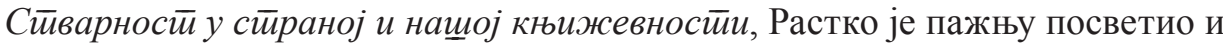
америчком приповедачу Џеку Лондону чија га је проза фасцинирала због испреплетаности судбине човека и природе у „огромној катаклизми америчког живота“ (Петровић 1974: 231). Сва динамика модерног света као да се, више него било где, испољава у Америци, у борби елементарних сила и исконских порива у неспутаном хуку живота:

„Џек Лондон је свој живот био сплео са великим захукталим животом Америке; он је био тачно где је земља крчена, где је човек јурио за златом, за крдима, где су са скорашње горе и јучерашње паше израсле џиновске зграде и фабрике, и где су се људске руке измешале са мразевима, са точковима и кајишима машина, и где су људи били ломљени од вукова, цикона, експлозија мотора. Он је био тачно где се човек хватао у коштац са алкохолом, са зверима, са човеком. У сваком реду он описује борбу бића и елемената, за постојање или не“" (Петровић 1974: 232).

Убрзо по доласку у Чикаго Растко је направио план за други део Дана $\underline{m e c \bar{u} о \bar{~} к о ј и ~ ј е ~ т р е б а л о ~ д а ~ б у д е ~ ј е д н а ~ џ е к л о н д о н о в с к а ~ ф р е с к а ~ м о д е р н е ~ А м е-~}$ рике у којој је човек растрзан између сурових правила опстанка у индустријском друштву и „зова дивљине“ ирационалних порива. Међутим, пре него што се задржимо на Растковом позном књижевном стваралаштву важно је поменути околности његовог живота у новом свету које ће битно утицати на модификције првобитних списатељских намера.

На основу сачуване дипломатске (Петровић 1994) и приватне преписке (Петровић 2003) видимо да се Растко у Америци брзо и успешно снашао, и као дипломата и као уметник. Одржавао је везе са бројним угледним личностима из академских кругова - Ренеом Ентијамблом и Ђузепеом Боргезеом, професорима књижевности на Универзитету у Чикагу, потом Андреом Бретоном и Сен-Џоном Персом, који су за време Другог светског рата боравили 
у Сједињеним Државама. За Растка, али и за нашу књижевност, драгоцено је било познанство са Албертом Лордом, тада младим славистом, који ће превести први део романа Дан щестии и на енглески језик. Велико задовољсто Растку су била и путовања по савезним државама, затим по Канади, Мексику и Куби, за која се пажљиво и студиозно припремао. Интересовао се за антропологију и етнологију, посебно га је занимала култура Индијанаца (данас их, у духу политичке коректности, називају Native Americans) и афро-америчка духовна музика. Заправо, могло би се рећи да је Растково стварање у Сједињеним Државама обележено његовим већ успостављеним авангардним интересовањима формираним у Паризу након Великог рата, где је упознао Пабла Пикаса, Андреа Бретона, Филипа Супоа. О њима не само да је писао након повратка у Београд него је париско авангардно искуство уткивао у своју прозу и поезију. Већ у Бурлесии їосйоgина Перуна бої їрома (1921) и Ойкровенуу (1922) видне су кључне одлике Петровићеве поетике која је у знаку синтезе модерних поступака, какви су колаж, монтажа и симултанизам, и мотива из словенске митологије, српског фолклора и древних архетипова.

Након избијања Другог светског рата дипломатска активност Растка Петровића постаје интензивнија. У јуну 1942. године у посету Сједињеним Државама из Лондона, где је било седиште југословенске избегличке владе, стиже краљ Петар II Карађорђевић. Као секретар посланства у Вашингтону, Растко га је пратио приликом посете председнику Рузвелту. Из тог времена датирају и Расткови контакти са Јованом Дучићем и Николом Теслом као и са уметницима који су из Европе емигрирали у Америку. Пажње вредно је и Растково учешће у објављивању антологије Heart of Europe коју су 1943. приредили Клаус Ман и Херман Кестен. За ту књигу, посвећену модерној књижевности старог континента који је тада страдао у паклу рата, Петровић је, као уредник за део о југословенској књижевности, одабрао и превео три текста: одломак из приповетке У їостиима Драгише Васића, потом приповетку Сйаноја Борисава Станковића и песму Милана Дединца Како умиру тиихи (MANN - Kesten 1943: 358-377).

По доласку у Сједињене Државе Растко је одлучио да напише наставак романа Осам неgеља. Већ крајем 1936. писао је о томе Милану Дединцу. У поетичком дослуху са Лондоновим Зовом дивљине, Џојсовим Улисом и Хакслијевим Конйрайункйом, делима које је високо ценио, Петровић је замислио роман који би симултано пратио велики број ликова током једне ноћи и то искључиво на отвореном простору, у непрекинутом континуитету равница, шума, друмова и градова:

„Око три стотине личности укрштају своје судбине. У ствари то је једна људска џунгла где је сваки човек врло дивља, кротка и нагла животиња, не толико дисциплинована радом колико дисциплинована ради рада. Њихов рад је под директним дуплим обележјем дивљине која је у њима и дисциплине на коју су пристали. (...) Све би се догађало у Америци, 
јер ту доживљавам такву визију, јер су ту гужве белих, жутих и црних народа, с удруженим збивањима, и јер је ту човек можда најсавршенији travaillé par le travail, чему иде разним путевима све људство“ (ПЕтровић 2003: 234-235).

Наставак ратне епопеје из романа Осам неgеља требало је да буде епопеја индустријске цивилизације у којој људи живе као дисциплиноване животиње. Ова амбициозно замишљена контрапунктска композиција, чију монументалност Растко пореди са фреском, смештена у уликсовско јединство времена, представили би појединце који радом изграђују своје животе а сви заједно целину друштва. Иако је имплицитна критика друштвених институција, производних односа и отуђености човека у капиталистичком систему добила место у коначној верзији Дан щестй $и$, у роману ће ипак превладити другачија, „пасторална“ слика Америке. Уместо социјалног и егзистенцијалног немира успоставља се утопијска концепција у којој, да се позовемо на размишљања Херберта Маркузеа, „слободни људи (или радије људи у пракси свог ослобођења) обликују свој живот у солидарности и граде окосницу у којој борба за егзистенцију губи своја ружна и агресивна обележја" (MARCUSE 1972: 168). На обликовање такве визије утицала су Расткова путовања, поготову по Вирџинији и Њу Хемпширу, као и откривање индијанске традиције, која се, уз идиличну природу, указује као алтерантива отуђењу и нелагодности коју јунаци осећају у граду. Слично Клоду Леви-Стросу који је, проводећи Други светски рат у Њујорку, био фасциниран контрастима и суживотом различитих култура, због чега му се највећи амерички град чинио као „антрполошки сан“ (LEVI-STRAuss 1992: 262), и Растко је Америку доживљавао као „гужву белих, жутих и црних народа“ која стално производи нова социјална, уметничка и хуманистичка значења и изазове. Коначно, до јунака̂ другог дела Дана ще естй 1938 , допиру одјеци политичке кризе и идеолошких сукоба који су у предвечерје рата све више обузимали Европу. Насупрот старом континенту, Америка се у том тренутку указује као сигурно прибежиште, оаза мира за главног јунака Стевана Папа-Катића који је прошао кроз ужас албанске голготе.

Други део романа Дан щестии није био прво дело наше књижевности чија се прича одвија у Америци. Половином тридесетих година, тачније 1934, објављен је путопис Нови свет̄ Јелене Димитријевић, ауторке чији приповедачки опус је тек у новије време постао предмет интензивнијег проучавања и вредновања. Убрзо након окончања Великог рата ова списатељица се, бежећи из разорене Европе, упутила преко океана и на америчкој истичној обали провела годину дана, највише у Њујорку. Под утиском величине и моћи градова који се убрзано развијају гомилајући огромно богатство, Јелена Димитријевић оставила је упечатљива сведочанства о формирању модерног америчког друштва које промовише слободу и права појединца али у исти мах почива на суровим класним разликама и расним дискриминацијама. 
Различити доживљаји новог света у прози Јелене Димитријевић и Растка Петровића не произилазе само из другачијих жанровских уобличења, па ни из односа сликаิ градова и визијаิ природе, него првенствено из различитих родних перспектива. Јелена Димитријевић Америку посматра и о њој суди као политички ангажована жена (DoJČINOVIĆ 2019). Ипак, неке додирне тачке између ових књига, ипак, постоје. Од свих градова у путопису Нови свете, као најлепши и за живот најпријатнији издваја се Вашингтон, који и у Растковом роману има повлашћено место. И српска списатељица и главни јунак Дана 쓰르ํ у нови свет одлазе бежећи од трауматичног историјског искуства, што битно одређује њихово виђење Америке, која се убрзано развија у другачијим цивилизацијским оквирима у односу на Стари континент.

Док је прва књига Дана щесейо̄ тематизовала ратну голготу као потпуно урушавање свих хуманистичких и моралних вредности, „еволутивно кретање у назад, до времена пећинских људи, изједначавања човека и животиње, претварање тела у фосиле и минерале, растварање у блату и силазак у море као примордијалну материју“ (Петровић П. 2013: 196), њен амерички наставак одвија се у оквирима модерног, високо развијеног друштва и разуђене мреже социјалних, академских и политичких односа. Стевана Папа-Катића затичемо у Вашингтону, као угледног универзитеског професора, палеонтолога, задивљеног пред хармоничном закономерношћу универзума. Индикативно је да у Растковом роману хронотоп града нема ни приближно онакав значај као у делима његових модернистичких сапутника, Џојса, Дос Пасоса или Алфреда Деблина. Зашто је тако, најбоље открива један од ретких описа модерног града у Дану щестиом, језгровит, ефектан и дат на врло специфичан начин. Један од епизодних ликова, Драгиша, Стеванов вршњак, у вашингтонском кафеу посматра конобара који му прилази и у његовој појави види обрисе „монстуруозног“ динимазма урбаног простора који у човеку гаси виталистичку енергију и претвара га у покретну руину:

„Драгиша се загледао један тренутак у његову блузу, изукрштану љубичастим и плавим светлосним одблесцима. Мрачне зграде, сјајне и мукле експлозије реклама, зрачни прах, тискање људи, све је то изгледало монструозно и као набацано на ову људску прилику која је чекала пред њим. То није било људско тело - тај човек - сједињено и јасно у свом склопу, већ нека невероватна пирамида најразнороднијих елемената, нестабилна, покретна, у сталном напору да одржи равнотежу и да се не разруши“ (Петровић 1974: 511).

Стеван Папа-Катић своју духовну равнотежу успоставља предајући се науци, природи и имагинацији, далеко од градске вреве и њеног рекламног сјаја. Док пролази улицама америчке престонице, он нема никакво интересовање за њен ужурбани живот. Својом имагинацијом он се креће непрегледним пространствима Аризоне: „Хтео ја да је тамо. Да је на широкој осунчаној пустари на којој ветар ваља лопте сасушеног биља а сиве животиње 
искачу из сенке кактуса носећи младунце на прсима, срце уз срце“ (Петровић 1977: 441).

Након ужаса ратне дехуманизације Стеван је, на крају првог дела романа, изгубио веру у људе. Одласком у нови свет он се, усамљен и разочаран, у потпуности посветио науци, затварајући се за било какав интимнији однос или за интензивнију социјалну комуникацију. У окриљу природе он покушава да нађе рајско прибежиште. Топос пронађеног раја један је од најважнијих хронотопа Расткове прозе, од старословенске, деволске долине у Бурлесии, дивљине Црног континента у путопису Африка, једноставног рибарског села у кратком роману Љуgи іоворе па до америчке пасторале у другом делу Дана щестиов. Док заокупљен имагинацијом бескрајних простора и времена универзума пролази улицама Вашингтона, Стеван ће за тренутак застати пред чудесним вртом који се, попут откровања, указује у градској гужви, ограђен бамбусовом трском - „врт се разбуктавао као пожар, освојио све, загушио, распламтео и понео све у висину. (...) Ниједно људско биће није више живело у том врту који је силазио ка реци ширећи се нагло као поплава или пожар“ (Петровић 1977: 445). Топос раја у последњем Растковом роману призива и слику Америке која опстаје још од времена њеног открића и која ће у двадесетом веку бити позната као „амерички сан“", односећи се, наравно, на Сједињене Државе. „За картографију Новог свијета мит о рају био је од суштинског значаја, а према новијим историчарима он је значио повратак у замишљену прошлост, нарочито због тога што су, како је говорено, страосједиоци били лишени културе, одеће и хришћанства“"(Вукчевић 2018: 28-29). Растку је такво поимање Америке, као повратка у хронотоп среће замишљене прошлости, свакако блиско. Међутим, ни он, као ни јунаци његовог романа, не доживљава и не вреднују староседеоце као примитивне. Напротив, древна индијанска култура сачувала је у својој другости, у свом хармоничном односу са природом, оне вредности које би, у једној неминовно утопијској визији, могле бити упориште хуманијег друштва, о чему ће бити више речи касније. И силазак до реке Потомак за Стевана ће бити изузетно важан. Посматрања рибара на доковима, шум воде, пригушена светлост града - то су призори у којима он налази мир. ${ }^{1}$ На четврт рибарских кућа надовезује се Џорџтаун, стари, боемски део Вашингтона са каменим кућама и крчмама, где Стеван разговара са својим студентом Билом Гордоном. Управо захваљујући лику овог младића у роману се постепено уводе различити аспекти америчке културе, историје и књижевности.

${ }^{1}$ Развијенији опис Вашингтона налазимо у Растковом писму упућеном Марку и Шеви Ристић, октобра 1936: „Јесен је дефинитивно завладала Вашингтоном и дрвета које гледам су савим оголела, велики парк који почиње тачно испред наше куће и који се после претвара у праву гору, са пећинама, рекама и брзацима, блешти на сунцу го. Црнци силазе у поворци да пецају рибу. Они уосталом дају нарочити јужњачки чар овом делу Америке. Скоро је половина вароши црначка. Иза широких булевара седе по цео дан и по целу ноћ на степеницама дрвених кућа као пијани гроздови жена, људи и деце. Све у једном мору грамофонског шиштања и банџа“ (Петровић 2003: 38-39). 
Иако се смисао живота у Дану щестиом не формира толико у контексту друштвених и историјских дешавања колико спрам целине природе и процеса разградње и обнове који се у њој циклично одвијају, делови романа посвећени политичким дешавањима значајно доприносе формирању визије тоталитета људског постојања у модерном свету. У исти мах они се указују као смисаони контрапункт миру и хармонији коју Стеван и Бил налазе у окриљу природе.

Тема којом је Растко желео да се бави у првобитној замисли романа, о човеку који је у савременом друштву постао „дисциплинована животиња“, добиће место у неким размишљањима Била Гордона, бунтовника против друштва који чита Поа и Витмена и чини ходочашће индијанском резервату. Док шета са Стеваном Папа-Катићем улицама Џорџтауна, Бил је најпре у патриотском заносу: „Ми смо најбогатија и најлепша земља на свету и ја волим народ који живи на том тлу“ (Петровић 1977: 457). Међутим, иако воли људе, Бил истиче да не разуме њихову потребу да све посматрају кроз новчану вредност и конвенционалне друштвене игре и улоге које, свесно или не, прихватају. То су им једини сигурни ослонци којим покушавају да укроте или потисну ирационалне пориве који би сваког тренутка могли избити на површину. Учешћем у разним социјалним активностима и забавама модерни човек заправо жели да побегне од своје праве природе и да одагна или сакрије неку тајну:

„Зашто сви моји пријатељи, било да су постигли неки успех или нису, имају такав страх од себе самих и покушавају да нешто забораве, да од нечега побегну? И зато говоре непрестано о бициклима, фудбалу, аутомобилима, пословима, венчањима. Не смеју да заћуте или да остану сами један тренутак, јер оно што је скривено у њима, и није дубоко затрпано, може избити сваки час, и зато опет говоре о колима и пословима, а када више не могу да говоре онда пију. (...) Ми нешто кријемо у себи, ми се плашимо да нађемо нешто што је врло плитко затрпано у нама" (ПЕтровић 1977: 457).

У Биловим размишљањима могли би се препознати обриси Фројдових ставова с почетка тридесетих година прошлог века о нелагодости савременог човека који прихвата институционалне оквире и конвенције уређеног друштва да би се заштитио од својих страхова али у исти мах „постаје неуротичан јер не може да поднесе обим одрицања које му је наметнуло друштво ради својих културних идеала" (FROJD 1981: 291). Стеван на Билове констатације одговара ћутањем зато што и сам крије тајну о трагичном искуству дехуманизације коју је за време ратне голготе видео не само у другим људима, него је препознао и у себи.

Тема о судбини човека који живи у расцепу између јавне улоге на великој друштвеној позорници и интимних, скривених порива, биће настављена у сценама пријема које организује Билов отац, утицајни банкар Џек Гордон. Тада Стеван на тренутак долази у додир са америчком високом политиком 
у време председника Френклина Рузвелта, када америчка привреда и друштво излазе из економске кризе док се на историјском хоризонту указује претња новог светског сукоба. Стара, пространа кућа Гордонових у Џорџтауну крије у својој мрачној утроби остатке позоришне сцене на којој је, према урбаној легенди, играо Џон Вилкинс Бут само неколико дана пре него што ће убити Абрахама Линколна. Визија света као позорнице има важно место у модернистичком роману, поготову у позним остварењима Иве Андрића и Милоша Црњанског (Петровић П. 2018). ${ }^{2}$ У другом делу Дана щеесӣо̄ она је везана првенствено за тињајући раскол између пожељне и прихватљиве друштвене улоге коју игра појединац и, с друге стране, његових потиснутих страсти. Стеванов домаћин, Џек Гордон, крије своје лице коцкара и ловца „иза нечега што је представљало маску мудрости у незаустављивим струјама стварности“ (Петровић 1977: 501). Желећи да из прагматичних разлога буде спона између демократа и републиканаца, Гордон се залаже за општа начела слободе и правде која би требало да ограниче самовољу, али делом и индивидуалне слободе појединца. Узор му је Ендрју Џексон, оснивач Демократске странке и седми председик САД-а, од 1829. до 1837, познат као велики заговорник јединства америчке нације али и један од креатора закона о пресељењу Индијанаца, којим су Чироки и друга староседелачка племена насилно расељена на другу страну реке Мисисипи да би се створило више слободне земље за беле досељенике (REMINI 1981). Џек Гордон je, заправо, представник спреге финансијске и политичке моћи, актер незустављивог друштвеног прогреса. Уместо хуманистичким вредностима, такав напредак, вођен је интересима финансијске добити и постепено се указује као пројекат затварања човека у надзирани поредак потрошачког друштва. То је напредак проистекао из напора да се „дижу огромне нове куле конструкција и машина, хрпе уговора, робе, обвезница, законских предлога, закона, говора, хрпе хартија које представљају људски поредак, гомила челика и цигала које су уточиште и тамница за људе“ (ПЕтровић 1977: 493).

Као и у Растковом роману Са силама немерливим насупрот фигури моћног оца стоји син који има сасвим другачије интересе, ван конвенционалних друштвених оквира. Џеков син, Бил Гордон, већ се у разговору са Стеваном легитимише као младић склон критичком промишљању америчког друштва. Том приликом Бил ће исказати и своју страствену заитересованост за живот и дело Волта Витмена, првог великог песника Америке чија је поезија, слично Бодлеровој у Француској, била у сукобу са друштвом свога времена и зато оптуживана за неморал. Шетајући улицама Џорџтауна,

2 У Америци је Растко Петровић написао своју једину драму, Сабињанке. Иако јунаци имају англосаксонска имена и радња се дешава у амбијенту који је иманован као амерички, у овој драми „све делује некако чудно старовремски, као бледа реплика једног старог, одавно несталог Београда, из времена непосредни пре и после Првог светског рата“" (ФРАЈнд 1989: 244). Сабиґанке су и ликовима и радњом заправо драмске варијације на фигуре и теме из романа Са силама немерливим. 
Бил показује Стевану кућу у којој је живео Питер Дојл, Витменов пријатељ. Младићу није стало до саме куће колико до сећања на великог песника, заправо до оног поетског сензибилитата и интимног, аутентичног доживљаја света који, можда, сви Американци носе у себи али су једино Витменови стихови то храбро изразили. Ипак, модерни човек одриче се тог лирског и хуманистичког у себи у име вредности потрошачког друштва:

„Потпуно ми је у ствари свеједно да ли ће неко срушити ту кућу па на место ње подићи стоваришта, али не и да је Волт Витмен постојао, био плод овдашњег човечанства, да су га људи носили у себи пре него што се родио... Зашто се одричу онда оног дела себе из којег излазе људи као Волт Витмен? То је оно што не разумем...“ (Петровић 1977: 462)

Други део романа Дан щесеии ирхунац је Растковог дијалога са Витме-

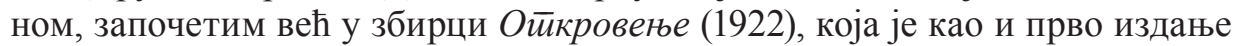
Влатии йраве (1855) имала дванаест песама праћених аутопоетичким есејом. Петровићеву блискост у доживљају света са родоначелником америчке поезије истакао је већ Милош Црњански одредивши Ойкровеље као „певање Витменово, само дечачком слабошћу, из које се рађа шарлоовска хуманост, гротескна љупкост, очај и љубав над апокалиптичним“ (ЦрњАнски 1991: 154). ${ }^{3}$ Слављење лепоте људског тела и сексуалности, доживљај континуитета трајања живота и природе, поимање креације као органског раста и „прогреса као последице креативне снаге у природи“ (ЛАлић 1997: 148), потом космичке визије пројектоване у историјски тренутак, супротстављање моралним кодексима грађанског друштва, изразито наглешни мотиви путовања као и ликова морнара и рибара, неке су од битних додирних тачака Витменове поезије и Растковог опуса. Тим поетичким везама придружује се у роману Дан щестии и слика Америке - њених непрегледних, пасторалних простора, цивилизацијског прогреса, мешавине раса и народа, демократског потенцијала. Билова љубав према родној земљи знатним делом извире из Витменових стихова, што је видно у поглављу Хоgочащће, које је поетичко језгро другог дела романа. Желећи да „оде некуда далеко, да потера кола мрачним друмовима“ (Петровић 1977: 474), Бил је попут лирског субјекта Витменових песама који жуди за препуштањем даљинама, утапањем у бескрај овоземаљских и небеских простора - „хрлим кроз простор, хрлим кроз небо и звјезде“, веле стихови Ујевићевог превода Пјесме о мени, док Витменова Пјесма о слобоgноме йуйу отпочиње строфом: „Пјешке и весела срца корачам слободним путем, / здрав, слободан, а свијет је преда мном, / дуги смеђи пут који ме води куда год хоћу“ (VITMEN 2015: 21, 61).

\footnotetext{
${ }^{3}$ Витменова поезија имала је велики утицај на европску и српску аванагарду. Како истиче Радован Вучковић „у свим покретима Витмен је фигура број један, чија им превратничка улога, снажана воља и варварска снаге лебди пред очима“ (VučкоVIĆ 1979: 42). У годинама пред Велики рат Витмен је био најпревођенији песник у утицајном часопису Босанска вила. Преводили су га, између осталих, Љубо Визнер, Боривоје Јевтић и Иво Андрић.
} 
Ходочашће који чини млади Гордон је вишеструко - то је посета индијанском резервату, поклоњење природи и универзуму али и америчкој књижевности и историји. Пре него што ће посетити резерват, Бил лута улицама Ричмонда у Вирџинији, једног од најстаријих америчких градова, који је за време грађанског рата био престоница Конфедерације, што ће се у завршном делу овог поглавља указати као важно. Међутим, Билову пажњу најпре привлачи једна књижевна чињеница. У Ричмонду је знатан део живота провео Едгар Алан По. Ту је 1837. године објавио свој једини роман, Аванӣире Арйура Горояна Пима, у часопису Southern Literary Messenger.

„Одједном у једној књижари он виде збирку Southern Literary Messenger од 1837. Отворио је свеску од јануара и прочитао: Волео ме gуї u йоййуно. Сто и једна година како је Едгар Алан По записао то баш у овом граду. Сто и једна година од Артура Гордона Пима. И он пође у малену кућицу у којој је Поов музеј. Гледао је сваку фотографију, сваки рукопис, шкриње и столице и сто на коме је можда песник писао. Једна стара дама показала му је фантастичне илустрације које је за Гаврана начинио сиромашни и трагични Џемс Виљем Карлинг пре него што ће се вратити у Ливерпул. Никада ни један илустратор својом сублимношћу и трагиком није био ближе Поу од овог јадног младића““ (Петровић 1977: 476-477).

Као и Волт Витмен, и Едгар Алан По био је готово култна књижевна фигура међу авангардним ауторима. ${ }^{4}$ У библиотеци „Албатрос“, у којој је објављен и Растков роман Бурлеска їосйоgина Перуна боїа іррома, појаво се 1922. годне избор Поових приповедака и песама под насловом Кюиі̆a $\bar{u} a-$

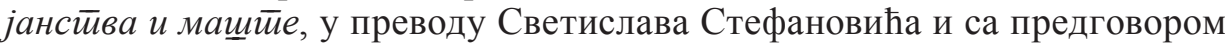
Станислава Винавера. Исте године Растко у Времену пише приказ у којем о „великој луталици Новог света“" вели да је успео, као ниједан књижевник до тада, да изрази мистерију људског постојања, саткану од случајности, фантастике и психологије. Петровић, ипак, жали што „ми немамо још преведене Аванйире Арйура Горgона Пима, које су најзамашнији романсијерски еп овога песника“" (Петровић 1977: 158). Зато овај мали омаж Поу у другом делу Дана щесейо̄ није ни мало случајан. Поред презимена, Бил Гордон са главним јунаком Поовог романа, који бежи у свет желећи да искуси пустоловине, дели страст ка путовањима као облицима неконвенционалног искуства и откривања новог и другачијег. Сажета прича о уметнику Џејмсу Виљему Карлингу (1857-1887), илустратору Гаврана, свакако упућује на Расткова интересовања за однос ликовног и текстуалног медија,

4 Занимљиво је да почетком двадесетих година прошлога века авангардни уметник Бошко Токин у својим манифестима велича америчку културу коју репрезентују По, Витмен и, у новије доба, Чаплин. У тексту „USA = Po, Whitman, Chaplin“ Токин истиче да су ова тројица уметника „највиши духовни покретачи, почеци, свечовечански изрази. Они стварају Америку, они стварају Европу“ (Токин 1994: 78). 
који је испољен у богатим значењским везама графика и песама у збирци Ойкровење.

Након обиласка Ричмонда, Бил проводи дан у Памуки резервату у Лестер Манору, потврђујући Витменов програмски став, изречен у предговору збирци Влатии тираве, да „амерички песници треба да обухвате старо и ново јер Америка је раса раса̂“" односно да „овде није тек једна нација већ нација која врви од нација̄“" (ВитмАн 2015: 70-71). Овакав доживљај Америке доћи ће до пуног изражаја у Растковим кратким, аматерским документарним филмовима које је снимао пред Други светски рат, као и у његовом интензивном проучавању индијанске културе и традиције. Оно што фасцинира Била и његове пријатеље, док са америчким староседеоцима бораве у природи и лове рибу на језеру, јесте континуитет људског присуства које траје на тим просторима, много пре заснивања културе белог човека: „Младићи су се обрадовали њима јер су били доказ да је човечанство проносило овим пределом своје болове и радости већ годинама и поколењима и да их је мешало са шумама и облацима и ваздухом и водом“" (ПЕтровић 1977: 478). Једноставан, идиличан живот поред језера, стопљен са природом, близак је оном који је Растко описао у кратком роману Љуяи іоворе (1931). Међутим, однос природе и културе у опусу Растка Петровића само је на први поглед разрешен опонирањем или, пак, некаквим русоовским тражењем у природи оне изворности и аутентичности које друштво не поседује. Визије природе и универзума у другом делу Дана щестйоі заправо су вишеструко посредоване симболима и знањима произведених културом. И онда када демонстративно напуштају град и попут ходочасника посећују индијански резерват, као што чини Бил Гордон, или се отискују од европског континента у сусрет црном телу у путопису Африка, протагонисти Расткове прозе природу виде и „кроз мрежу саткану од веровања, знања и постављених циљева, тако да заправо делују у оквирима културних представа о природи, а не у оквирима стварне структуре природе“" (RAPPAPORT 1971: 246).

Та мрежа историјских, књижевних и интимних знања и алузија посебно долази до изражаја у Биловом доживљају целине ноћног универзума, у распону од дубине земљине утобе до сјаја звезданог неба, док лежи на падинима Хенри Хауз-Хила. У јунаковим медитативним и лирским рефлексијама назире се нејасно сећање на битку која се некада давно ту одиграла. У питању је прва велика битка Америчког грађанског рата, позната као The First Battle of Bull Run, вођена јула 1861. (SALOMON 2001: 17-21). Док затворених очију нежно милује земљу, Бил се препушта поетској имагинацији историje, замишљајући погинуле младиће, који су припадали зараћеним странама Уније и Конфедерације, како сада, измерени и загрљени у смрти, спавају у уторби земље. „И Бил се надвио над њихова млада, успавана и мртва тела и гледао је њихов сан који је све мирио“ (Петровић 1977: 487). Мотив мртвих уснулих другова присутан је Растковим дужим песмама инспирисаним Првим и Другим светским ратом. Тако у завршници поеме Велики gру $\bar{\imath}$ (1926), посвећене вршњацима страдалим током повлачења преко Албаније, 
натуралистичка слика смрти у снегу претвара у се визију вечитог сна: „Видим божанског друга: спи, у срцу снежног брега!“ (Петровић 1974: 218). Тај мотив биће још изразитији у Растковим остварењима насталим почетком четрдесетих година у Америци, под утиском трагичног братоубилачког рата вођеног у Југославији. Песма Шйа $\bar{u} и$ кажу очи ґине завршава се стиховима: „Сада леже приљубљени / Умирени, насмешени / Усред ове чарне горе / Ко̂ да један другог дворе / Моја зоро и мој дане, / Кô да један другог бране, / Од туђина и душмана / До судњега оног дана“ (Петровит 1974: 179). Ипак, Билова визија погинуле браће и другова након битке код Хенри Хауз-Хила готово је идентична стиховима Расткове песме инсприсане вешћу о сестрићу који је као борац равногорског покрета погинуо у борби са партизанима (Сећағе на млаgов сестирићa). ${ }^{5}$ Међутим, ту није крај песничким прожимањима. Непрекидни континуитет нестајања и настајања, слике раскошног бујање природе која ниче из земље у којој су похрањена тела давно умрлих бића, битно су обележје доживљаја света у и Витменовој поезији. У песми То Ђубриво натуралистички описи телесног распадања укрштају се са дивљењем пред величанственом хемијом универзума који из смрти „цеди“ животворне сокове за раст нових бића.

У завршници поглавља Хоgочащће дискретно се успостављају везе између америчке и српске историје, између два трагична грађанска, братоубилачка сукоба - једног који се на тлу новог континента водио средином деветнаестог, и оног који се у Југославији одвијао за време Другог светског рата. Те везе су дискретно сугерисане не само због лирског тона и поетских визија, него и зато што се други део романа одвија од средине јуна до средине новембра 1938. Други рат још није почео, али се његов долазак слути, помиње се успон фашизма у Немачкој, прогон Јевреја, криза поводом Судета, политичке прилике у Југославији. Интегрисање у роман стихова насталих поводом погибије сестрића свакако указује на то да је Растко наставак Дана ще $е \bar{u} о \bar{\imath}$ писао за време Другог светског рата и да су та трагична збивања битно утицала на коначно уобличење уметничке слике света и смисла људског постојања, као што је тај историјски догађај оставио видан траг и у Анрићевом роману На Дрини ћуйрија и Друіој књизи Сеоба Црњанског.

\footnotetext{
5 У роману тај део гласи: „Сада је све прошло. Никад више и нигде неће више неће се обновити оно што сте били ви. Лепота духа и тела. Никад више ваше усхићење. У вечери, загрљени са својим женама, насмешени на једно друго поколење. Сада су сви путеви пусти вас, жудни вас, жедни вас. Спавајте и сањајте, добри другови, још у мом срцу имаћете свој гроб“ (Петровић 1977: 488). Последње две строфе песме Сећање на млаgої сестирића готово да су идентичне: „Сада је све готово. / Никада више и ништа више / Од лепоте тела и духа што се у вама обзнанила. / Никада више нада / Да ћу своје уморно срце положити у ваше младе руке / Да га покопате крај путева којима пролазите / У вечери, загљени, са својим женама, насмешени на / једно даље покољење. / Сад су путеви пусти ја ћу остати сам и пуст... // Спавајте и сањајте, / Спавајте и сањајте, добри другови, / Још у овома срцу неко време имаћете свој гроб“ (Петровић 1974: 193).
} 
Велика синтеза удаљених историјских и културолошких искустава и знамења уочљива је и у завршници романа, када Стеван Папа-Катић у тренутку смрти, након што га је погодио залутали метак у шумама Њу Хемпшира, има визију старословенског дома у којем га чекају мртви пријатељи. Стари Словени „риђих коса и плавих очију“ (Петровић 1977: 607) израњају у пејзажу пасторалне Америке. Уместо Стеваног тела његова супруга Милица види „мртвог јелена са дивним витим роговима, са влажним очима и тамним ноздрвама““(ПЕтровић 1977: 608). У древној словенској као и у већини европских митологија јелен је хтонска животиња која „одводи душе умрлих, које и саме могу имати облик јелена, на други свет“ (СРЕЈовић 2001: 23). Међутим, због својих рогова који сваке године отпадају да би идуће године поново израсли већи и снажнији, јелен ,уједињује на најлепши начин смрт и поново рађање, васкрсење и бесмртност“(СРеЈовић 2001: 15). Ова животиња нема само култни сатус у словенској него и у индијанској митологији, коју је Растко, од доласка у Сједињене Државе, студиозно проучавао. У индијанском резервату Билу и његовим пријатељама домаћини су Зелени Јелен и Брзи Јелен. Према веровањима, плесовима и космогонијама северноамеричких староседелаца јелен је у вези са циклусима обнављања природе, плодношћу и стаблом живота (ALEXANDER 1999: 55), симболима који су уписани у целину Петровићевог романа. Коначно, борба јелена и обредне игре америчких Индијанаца остаће забележне и у Растковим документарним филмовима.

У исто време док је писао други део романа Дан щестии, Растко Петровић почиње да се интересује за изражајне могућности још једне уметности - филма. Од пролећа до касне јесени 1939. године својом камером снимио је неколико кратких, аматерских, документарних филмова у укупном трајању од тридесетак минута. Ови снимци свакако имају већу документарну него уметничку вредност. Међутим, сама чињеница да је њихов аутор велики књижевник, даје им значај. Они сведоче о неким Растковим интересовањима која могу бити важна за разумевање његових позних књижевних остварења, али и о томе како је овај стваралац видео и доживео Сједињене Државе крајем тридесетих година прошлога века. Коначно, ови снимци дају изузетну могућност да Америку буквално посматрамо Растковим очима и да поделимо његово одушевљење како том културом тако и филмом као документарним и уметничким медијем.

У Музеју Надежде и Растка Петровића у Београду чувају се три филмске траке, у боји и без звука, на којима су записи из индијанских резервата у Рочестеру, у држави Њујорк, и у Ричмонду, у Вирџинији, потом сцене које приказују Њујорк и Чикаго и, коначно, кадрови снимљени на пољима и у шумама Вирџиније или Њу Хемпшира. ${ }^{6}$

\footnotetext{
${ }^{6}$ Расткове филмове открила је и представила их јавности Радмила Шуљагић, кустос
} Музеја Надежде и Растка Петровића, најпре у емисији ТВ Београд Камером умесиио иеера, децембра 1986, затим, годину дана касније, на књижевној вечери у Народном музеју у Београду и, потом, у тексту Прича о филму објављеном у Књижевној речи (ШуљАгић 1988: 6-7). 
Од свог доласка у Америку Растко се интересовао за обичаје, игре и песме америчких Индијанаца о чему сведочи преписка са Смитсонијан институтом из Вашингтона, Катедром за антропологију Колумбија универзитета у Њујорку и Музејом уметности и науке у Рочестеру. У његовој библиотеци сачуване су књиге и научне студије о животу Индијанаца, као и плоче на којима су снимљене њихове песме и музика. Како је долазио до те грађе, види се, између осталог, из његових дописа упућених компанијама које су издавале грамофонске плоче са тонским записима индијанске музике. Америчка радио корпорација (RCA) марта 1939. нуди му колекцију плоча на којима су снимљене Орлова иесми, Песма змијске иірре, Зов сунчевої изласка, Иіра јелена, Разиірана сйойала и многе друге песме и игре америчких староседелаца (Петровић 2003: 61-62). Као што је у студији Млаgићсииво нароgної іенија (1924), која је у исти мах и антологија народних умотворина, претходница $O g$ златиа јабуке Васка Попе, описивао и тумачио додоле и игре русаља у селима у околини Пожаревца, или као што је писао о ритуалним играма афричких домородаца, Растко је своја антрополошка и етнографска интересовања у Америци посветио животу и традицији Индијанаца.

У пролеће 1939. године Петровић је, на позив Артура Паркера, директора Музеја у Рочестеру, посетио резерват Тонаванга, на западу државе Њујорк, где живе племена Сенека и Кајуга, и присуствовао свечаности отварања општинске зграде. „У исто време“, пише у Паркеровом позиву, „могли бисте имати срећу да видите више индијанских манифестација, укључених у пројекат којим овај народ рехабилитује своје старе уметности“"(ПЕтровић 2003: 54). Филмском камером Растко је забележио свечаности које почињу родеом а настављају се ритуалним плесовима и вашарском забавом. Индијански народни обичаји овде су били прилагођени модерним временима и у великој мери су сведени на забаву и атракцију која је изгубила своју изворну, магијску основу. На почетку филма виде се млади Индијанци обучени у конвенционална грађанска одела, културно асимиловани и интегрисани у белу популацију. За потребе свечаности, „пројекта“, како вели Паркер, они ће на кратко обући традиционалне ношње и само перформативно, дакле костимирањем и театрализацијом, потврдити свој изворни идентитет, односно то да су Други. „У складу са Бартовим схватањем да позирање за фотографију подразумева прављење неког другог тела које модел тера да се унапред преобрази у властиту слику, Индијанци то чине са пуном свешћу о функцији визуелне трансформације“" (SRETENović 2003: 97). Ипак, чини се да Растко и у тим свечаностима проналази остатке древног колективног искуства које је успело да опстане у савременом свету. У тим филмским записима откривамо и нешто до онога што одликује Петровићеву прозу. То су екстаза тела, слављење живота и мноштво пажљиво одабраних визуелних детаља.

Неколико месеци касније, у јесен 1939. године, Растко је боравио у Памуки резервату, који се налази уз истоимену реку у близини Ричмонда, у Вирџинији. Основан средином седамнаестог века (1658.), то је један од најстаријих индијанских резервата у Сједињеним Државама (ADAIR 2013). Управо 
ту се одиграва радња поглавља Хоgочащћћ из романа Дан щеестии. Ово је јединствен пример да један аутор исти простор уметнички уобличи у два медија - књижевном и филмском. Позивајући своје пријатеље да му се придруже на путовању, Бил Горон каже:

„Слушај, Ненси, хајдемо некуд далеко одавде. Ја знам иза Ричмонда један индијански резерват где ћемо бар један дан лутати ливадама и ловити рибу. Пливаћемо у реци са индијанском децом. Никад у животу више нећу да пијем. Одсада ћу ловити рибу са Индијанцима, купати се у њиховој реци, играти са њима ву-ву. У ствари, ово је њихова земља и неко задовољство треба да им учинимо“ (Петровић 1977: 474-475).

И у роману и у документарним филмовима Растко је исказивао велико поштовање и дивљење према култури америчких староседелаца. Иако су Индијанци у то време имали одређену институционалну заштиту, тврдње да је Америка изворно њихова земља коју су европски досељеници насилно отели, биле су у Сједињеним Државама тога доба готово попут јереси. Могло би се заправо рећи да је и по томе Петровићев Бил Гордон претходник јунака̂ култног, аутобиографски заснованог, романа Џека Керуака На йyйy (1957). Жудећи за слободним и аутеничним животом, Керуакови јунаци се отискују на путовања дуж америчког континента, путовања која ће у једном тренутку назвати управо ходочашћима, откривајући различита искуства и облике друштвене маргине, од џез музике до индијанске културе. ${ }^{7}$ Ритуални плесови које је Растко снимио у Памуки резервату нису били костимирана представа за публику као они у Рочестеру. То су древне обредне игре посвећене култу земље и плодности и оне су суштински и саставни део живота староседелаца, који се према Растку Петровићу односе као према драгом пријатељу. Као и у Хоgочащћу или кратком роману Љуgи іоворе, у овом филмском запису, који има одлике етнолошког документарног филма, видљив је Растков хронотоп среће: једноставан живот у природи, пред језера, разговори са људима, јединство и хармонија између човека и универзума.

Осим живота и обичаја Индијанаца, Растко је у својим кратким филмовима забележио призоре из два америчка града, Чикага и Њујорка. Ови филмови су занимљиви и због тога што у Растком роману нема развијених призора и описа градског живота. У лето 1939. у Чикагу је камером снимио кадрове плаже на обали Мичигенског језера. Дакле, од читавог града пажњу му је привукла управо ова природна лепота у којој људи, опуштени и обнажени, уживају. Ови снимци слични су доживљају Чикага које је Петровић поделио са Милицом Ракић у писму из марта 1936 године:

${ }^{7}$ Пажње је вредно и то да приповедач Керуаковог романа са Петровићевом поетиком дели идентичну, у Фројдовој психонализи засновану, визију изгубљеног раја који је човек доживео у мајчиној уторби: „Једино за чим чезнемо за живота, што нас тера да уздишемо и јечимо и пролазимо кроз слатке мучнине свих врста, то је сећање на неко изгубљено блаженство, доживљено вероватно у мајчиној утроби, које се репродуковати може једино (мада нам је мрско да то признамо) у смрти“ (KERUAK 2015: 169). 
„Језеро које видим кроз прозор плави се, не баш као залив у Напуљу али као најлепше дубровачко море, и људи, и аутомобили, и булдинзи протежу се од усхићења што је најзад топло, што жене најзад имају сламнате шешире на главама и људи одмах беле ципеле. Замислите како изгледа четири милиона људи свих народости првог дана пролећа““ (ПЕтРовић 2003: 229).

Снимци људи који се безбрижно забављају, сунчају и пливају настали су непосредно пред почетак Другог светског рата у Европи. Међутим, тај рат је, лета 1939, од америчког тла далеко. Овде се примећује још један важан моменат Петровићевог доживљаја света. Као што је на фотографијама које је снимао у Африци, овековечио домороце чија се тела пресијавају на сунцу, тако је и овде камером снимио људе у изазовним позама, жељне сунца и уживања. Нешто другачији су филмски записи из Њујорка, али Растко је и овде нашао специфичан угао посматрања. У мегалополису какав је Њујорк, Петровић је опчињен суживотом различитих народа и култура на истом простору. Поред призора свакодневних дешавања на улици, највише пажње добила је игра великог папирног змаја на прослави Кинеске Нове године у њујоршкој Кинеској четврти. Дакле, то је опет карактеристично Растково интересовање за древне традиције које, у различитим облицима, опстају у модерно доба. То је управо онај Њујорку који је Клод-Леви Строс тих година доживео као антрополошки сан, због мноштва културних, религиозних и историјских традиција које опстају једне поред других, што тај град и данас чини јединственим. Сличан сан у Њујорку и Америци проживљава тада и Растко Петровић.

Последњи снимци потичу из новембра 1939. и начињени су вероватно у шумама Вирџиније или Њу Хемпшира. Растко снима величанствену јесењу природу: шуме, реке, поља и, на крају, борбу јелена. Ови снимци у директној су вези са доживљајем природе на завршним страницама романа Дан ееии. Док хода шумом размишљајући о биолошким и космичким законима вечитог обнављања, Стевану се чини да се вратио у завичај:,Корачао је даље кроз шуму, благим косама, избијајући с часа на час на чистине и налазећи се на бреговима изнад Саве и Дунава, негде где се његов дух зачео, где се ево, дух једног новог бића зачео“ (Петровић 1977: 603). Растко Петровић, као и јунаци његовог романа, волео је лепоту америчке природе можда највише због тога што га је она сећала на завичајне просторе у Србији. На завичај га свакако нису могли подсећати велики градови, али се зато у природи препуштао лирским и носталгичним тренуцима, присутним како у његовој прози тако и филмским записима из тога доба.

Крај Другог светског рата и долазак у Вашингтон новог југословенског амбасадора, Станоја Симић, изасланика комунистичког режима, означио је крај Расткове дипломатске службе. Његова позиција у америчкој престоници била је тада, у другој половини четрдесетих година, слична емигрантској судбини Милоша Црњанског у Лондону. Оставши без посла, Растко је 
покушаво да живи од књижевног рада, али без већег успеха. Из тога доба датира његова преписка са Албертом Лордом који преводи први део Дана щесейо̄ на енглески. ${ }^{8}$ Растко је имао планове за нове књиге. У Конгресној библиотеци почео је да сакупља грађу о роману који би се дешавао у ренесансној Италији, о чему сведоче његови есеји, објављени на енглеском језику у париском часопису Gazette des Beaux-Arts, „On the Crossroads of Two Destinies: Corregio and Michlangelo“(1945) и "Questi Schiavoni (Those Slavs)“ из 1947 године. Нарушеног здравља и окружен малим бројем пријатеља који су га материјално помагали, Растко Петровић умро је у педесет првој години од срчаног удара у Вашингтону августа 1949. Сахрањен је по православном обичају на гробљу Стеновити поток, у сенци великог храста, под „каменом плочом, положеном равнодушно / У траву, посну и строго подшишану“, како то веле, над Растковим гробом испевани, стихови Ивана В. Лалића (ЛАлић 1997: 69). Посредством Петровићевог пријатеља, француског дипломате Арнолда Ваплера, рукопис Дана щесейо̄ стићи ће у Београд и бити у целини објављен 1961. у редакцији Марка Ристића и Милана Дединца. ${ }^{9}$ Посмртни остаци Растка Петровића пренети су Србију јуна 1986. и положени у породичну гробницу на Новом гробљу у Београду, уз присуство бројних књижевника и поштовалаца.

Тек што је стигао у нови свет, Растко је, у писму Марку Ристићу, октобра 1936, изразио наду да ће се ускоро поново видети са својим пријатељима и доживети срећу заједничког разговора као изузетног духовног испуњења:

„Ја знам само да сам волео живот, а шта сам под тим животом звао собом и уколико сам том љубављу био бољи, не знам. Не сматрам чак, и то је још тужније од свега да сам могао наћи бољи пут, и зато ми остаје као ретка, као можда једина, скупоценост да ћу се са тобом и са осталим својим пријатељима сретати опет и говорити са вама узбуђењем које у ствари неће ни представљати мене али ће ме увек испуњавати срећом“" (ПЕтровић 2003: 41-42).

Судбина му је, као и Стевану Папа-Катићу у роману Дан щесеии, одредила у Америци другачији крај.

\footnotetext{
${ }^{8}$ Рукопис тог превода чува се у Легату Марка Ристића у Српској академији наука и уметности. У последње време било је неколико покушаја, и у Србији и у Америци, да се овај превод објави, али, за сада, без успеха.

${ }^{9}$ Радован Поповић објавио је 2005. године у Лейойису Майице срӣске Ваплерову преписку са Марком Ристићем и Љубицом Луковић, Растковом сестром. На основи тих писама, до којих је дошао љубазношћу Никол Марић, удовице Сретена Марића, види се колико је пут Растковог рукописа до издавача био врло сложен (Поповић 2005).
} 


\section{ИЗВОРИ}

Витман, Волт. Предговор Влаӣима ӣраве (1855). Бојана Аћамовић (прев.). Поља LX/493 (2015).

Петровић, Растко. Есеји и чланичи. Јован Христић (прир.). Београд: Нолит, 1974.

Петровић, Растко. Поезија. Сабињанке. Јован Христић (прир.). Београд: Нолит, 1974. Петровић, Растко. Дан щеестии. Марка Ристића и Вере Стојић (ред.). Београд: Нолит, 1977.

Петровић, Растко. Дийломайски сӣиси. Миладин Милошевић (прир.). Београд: Просвета, 1994.

Петровић, Растко. Прейиска. Радмила Шуљагић (прир.). Београд: Меграф, 2003.

Токин, Бошко. USA = Po, Whitman, Chaplin. Авані̄арgни йисии као криӣичари. Гојко Тешић (прир.). Београд - Нови Сад: Институт за књижевност и уметност - Матица српска, 1994.

ЛАлић, Иван В. Сйрасна мера. Александар Јовановић (прир.). Београд: Завод за уџбенике, 1997.

Vitmen, Volt. Vlati trave. Tin Ujević, Ivan V. Lalić, Tihomir Vučković (prev.). Novi Sad: Mala knjiga, 2015.

KeruaK, Džek. Na putu. Tatjana Bižić (prev.). Beograd: Laguna, 2015.

\section{ЦИТИРАНА ЛИТЕРАТУРА}

Винавер, Станислав. Растко Петровић, лелујави лик са фреске. Крийички раgови Сйанислава Винавера. Београд - Нови Сад: Институт за књижевност и уметност - Матица српска, 1975.

Вукчевић, Радојка. Ист̄орија америчке књижевностии. Нови Сад: Академска књига, 2018.

ЛАлић, Иван В. О поезији Волта Витмена. О йоезији. Александар Јовановић (прир.). Београд: Завод за уџбенике, 1997.

Митић, Миодраг. Поет̄е у фраку. Београд: Филип Вишњић, 2002.

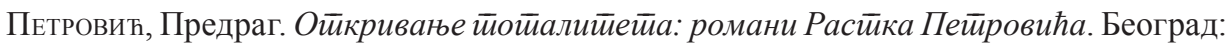
Службени гласник, 2013.

Петровић, Предраг. Свет као позорница у романима Иве Андрића. Дело Иве Анgрuћа. Зборник радова. Миро Вуксановић (ур.). Београд: САНУ, 2018.

Поповић, Радован. Растко Петровић - post mortem. Леӣойис Майице срӣске 181/476/3 (септембар 2005).

СРејовић, Драгослав. Јелен у нашим народним обичајима. Искусиива йрощлосиии. Видојко Јовић (прир.). Београд: Арс Либри, 2001. 
ФрАлнд, Марта. Сабињанке Растка Петровића - драма као путопис. Къижевно gело

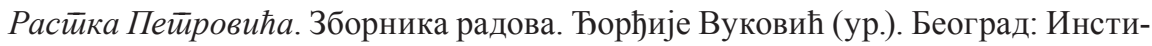
тут за књижевност и уметност, 1989.

ЦрњАнски, Милош. Есеји и йрикази. Бошко Петровић и Стојан Трећаков (прир.). Нови Сад: Књижевна заједница, 1991.

ШуљАгић, Радмила. Прича о филму. Къижсевна реч XVII/ 324 (25. јун 1988).

*

AdaIR, James. The History of the American Indians: Particularly Those Nations Adjoining to the Mississippi, East and West Florida, Georgia, South and North Carolina, and Virginia. (Classic Reprint). Cambridge: Cambridge University Press, 2013.

AleXAnder, Hartley Burr. The World's Rim: Great Mysteries of the North American Indians. New York: Dover Publications, 1999.

FroJD, Sigmund. Nelagodnost u kulturi. Iz kulture i umetnosti. Vojin Matić (prev.). Novi Sad: Matica srpska, 1981.

Dosčrnović, Biljana. Amerika Jelene J. Dimitrijević. Predgovor u: Jelena J. Dimitrijević. Novi svet ili u Americi godinu dana. Beograd: Laguna, 2019.

Levi-Strauss, Claude. New York in 1941. [1977]. The View from Afar. Trans. Phoebe Hoss. Chicago: University of Chicago Press, 1992.

Mann Klaus, Kesten, Hermann. Heart of Europe: An Anthology of Creative Writing in Europe 1920-1940. New York: L. B. Fischer, 1943.

Marcuse, Herbert. Kraj utopije. Esej o oslobođenju. Branka Brujić (prev.). Zagreb: Stvarnost, 1972.

RAPPAPORT, Roy. Nature, Culture and Ecological Anthropology. Man, Culture and Society. New York: Oxford University Press, 1971.

Remini, Robert V. Andrew Jackson and the Course of American Freedom, 1822-1832. New York: Harper \& Row Publishers,1981.

Salomon, John S. The Official Virginia Civil War Battlefield Guide. Mechanicsburg: Stackpole Books, 2001.

Sretenović, Dejan. U potrazi za prvobitnim. Otkrivanje drugog neba. Katalog izložbe. Urednici: Olivera Stošić, Mihajlo Pantić. Beograd: Kulturni centar, 2003.

VidAković-Petrov, Krinka. Serbian Americans : history, culture, press. Los Angeles: Sebastian Press, 2015.

VučKović, Radovan. Poetika hrvatskog i srpskog ekspresionizma. Sarajevo: Svjetlost, 1979. 
Predrag Ž. Petrović

\section{RASTKO PETROVIC AND THE AMERICAN CULTURE}

\section{Sum mary}

As many other Serbian writers from the beginning of the last century, Rastko Petrovic was also a diplomat. After spending several years in Yugoslavian embassy in Rome, in November 1935. Rastko came to United States, where he worked in consulates in Chicago and New York, and then in the embassy in Washington, where he was Charge d'Affaires. Rastko Petrovic continues to build his literary opus and artistic interests in America. His most significant work was the second volume of his novel Day sixth. Main character of the novel Migrations by Milosh Crnjanski, Vuk Isakovich, dreams of the magnificent russian steppes through which he will ride horses and live a free and authentic life. The hero of Rastko Petrovic's novel finds such happiness in land-scapes of America, far away from war torn Europe. While writing the second part of the novel Day sixth, Rastko Petrovic beggins to show great interest in expressive possibilities of another art form - movie. From spring to late autumn of 1939, Rastko made several short amateur documentary films with his camera. The value of this footage is documentary rather than artistic. However, the fact that their author is a great writer, certainly adds to their importance. These films represent some of Rastko's interests that are important for understanding his literary opus. Since his arrival to America, Rastko became interested in customs, dances and songs of Native Americans. Just like before, when he wrote about folk customs of eastern and western Serbia and about ritual dances of African natives, in America Rastko directed his interests to studying life and traditions of Native Americans.

Универзитет у Београду

Филолошки факултет

pedja611@yahoo.com 